\title{
Are all born equal? Incidence of febrile convulsions by season of birth
}

\author{
ROBERT SUNDERLAND, ROBERT G CARPENTER, ANGELA GARDNER
}

\begin{abstract}
To test whether the season of birth had an effect on subsequent experience of illness, details were obtained of all Sheffield children born between 1973 and 1977 who were admitted to hospital before their second birthday with a first febrile convulsion.

Analysis by date of birth in consecutive 28-day cohorts showed that the incidence of febrile convulsions ranged from 2.5 per thousand live births to 30.2 per thousand in different "month" cohorts. Statistically significant variations were noted in the incidence rates in relation to season and year of birth. The implication is that even large scale epidemiological studies which have been confined to children born in a particular week or month may not be representative of the whole child population.
\end{abstract}

\section{Introduction}

Several studies have sought information on childhood morbidity and mortality, based on cohorts of children born in a particular week or month. ${ }^{1-8}$ These cohorts were assumed to be representative samples of all children in that area at that time. Such studies, however, implicitly assume that the date of birth has no effect on a child's subsequent illnesses. Since this assumption has apparently not been explicitly tested, we decided to examine the incidence of febrile convulsions among Sheffield children aged up to 2 years born between 1973 and 1977 .

\section{Patients and methods}

Since 1973 birth histories have been recorded for every child born in Sheffield to residents in the city. Details of all hospital admissions in the first two years of life are obtained by daily contact with all the hospitals and linked to the birth records. Sheffield is a well-defined area, and there are no hospitals nearby to which children living in the city are likely to go. We have, however, not attempted to follow up infants born in Sheffield who leave the city either temporarily or permanently. Thus we have no information on admission to hospitals outside the city for infants for whom we have birth data. Equally we have not included in our analysis admissions to Sheffield hospitals of infants born outside the city. About $3 \%$ of the children moved out of the city before their second birthday, and a roughly similar number of children born outside the city moved in.

For the study we sought an index condition which was common in the age group, had a clear clinical diagnosis, and showed no evidence of seasonal variation in hospital referral. Febrile convulsions fulfilled these criteria. Also, we know that most convulsing children in Sheffield are seen in hospital, and, except for known epileptics, all are admitted for at least overnight observation. Most parents think that their child's first convulsion is life threatening and take the child directly to hospital. Sheffield's casualty departments are "open access" for children and have a policy of routine admission for all children after

Children's Hospital, Sheffield S10 2TH

ROBERT SUNDERLAND, MB, MRCP, registrar (present address: Department of Paediatrics, Gulson Hospital, Coventry CV1 2HR)

London School of Hygiene and Tropical Medicine, London WC1E 7HT ROBERT G CARPENTER, MA, PHD, senior lecturer in medical statistics ANGELA GARDNER, MSC, research fellow in medical statistics their first convulsion. To our knowledge all of Sheffield's general practitioners also request admission if they see a child after its first convulsion. If any convulsing children are kept at home, we are unaware of any selection based on the date of birth. Thus although our data may be incomplete, any omissions should not be systematically related to the date of birth.

Details of the children born between January 1973 and December 1977 who were admitted after their first febrile convulsion were abstracted for analysis. The children were then grouped by date of birth into consecutive 28-day cohorts. The numbers of children in each cohort were also obtained from the birth records.

The number of children of each sex within each birth cohort who were admitted after their first febrile convulsion was analysed with the GLIM program? using a logistic model which is appropriate to binomial data of this type. Walter and Elwood's test ${ }^{10}$ was also used to examine whether incidence varied with the season of birth.

\section{Results}

There were 27807 Sheffield children born in the period studied, 431 of whom had had a febrile convulsion before their second birthday. Table I gives the numbers of children in each 28-day cohort and those admitted after their first convulsion. Rates are shown for both sexes together because analysis had disclosed no significant difference in incidence between the two sexes. The overall mean rate was 15.5 children with febrile convulsions per 1000 live births, ranging from one in $407(2 \cdot 5 / 1000)$ in mid-1974 to 14 in 463 (over 30/1000) in mid-1976 (table I). The variation among-that is, between-these cohorts was larger than would be expected by chance $\left(x^{2}=150 \cdot 3\right.$; $\mathrm{df}=113 ; 0.01<\mathrm{p}<0.02$ ).

Table II shows that the rates tended to be higher in children born in the first part of the year than in children born later in the year $\left(\chi^{2}=24.7 ; \mathrm{df}=12 ; \mathrm{p}<0.025\right)$. Analysis of the incidence rates in table II using Walter and Elwood's method ${ }^{10}$ similarly rejected the hypothesis that incidence was not affected by the "month" of birth $\left(\chi^{2}=11.62 ; \mathrm{df}=2 ; \mathrm{p}<0.005\right)$. The seasonal variation in the rates in different birth cohorts may be described by a simple harmonic with a period of one year, a peak of 18.2/1000 in the fifth "month," and a trough of $12 \cdot 7 / 1000$ six "months" later (fig), the data being consistent with this pattern (goodness of fit $\chi^{2}=13.23 ; \mathrm{df}=8 ; \mathrm{p}>0 \cdot 1$ ). Thus the incidence rates varied by $17.9 \%$ either side of the mean rate of 15.5 per thousand depending on the "month" of birth. The rates also varied from year to year $\left(\chi^{2}=9.3 ; \mathrm{df}=4 ; \mathrm{p} \approx 0.05\right)$, being notably high among infants born in 1976 (table III).

\section{Discussion}

The season of birth reportedly has some effect on the incidence of stillbirths, ${ }^{11-13}$ congenital malformations, ${ }^{13-22}$ postneonatal mortality rates, ${ }^{23}$ and the subsequent development of several other disorders. ${ }^{24}$ Admission rates to hospital in the first year of life also vary greatly with the season of birth, ${ }^{25}$ possibly influenced by the age at which children enter their first winter.

At the outset of our analysis there was, however, no reason to suspect any systematic variation in the rates shown in tableI; in particular we did not suspect seasonal variation. We therefore investigated the general question, Is there a systematic variation between the sexes, between the month of birth, or from year to year? Month-to-month variation included the possibility of seasonal variation but also includes others which might have produced biannual oscillations or affected a particular cohort. A general test is inevitably less powerful for detecting seasonality than a specific test which examines seasonality alone. Thus by this approach we might have missed a seasonal effect, but had 
TABLE I-Numbers of liveborn Sheffield children in each 28-day birth cohort during 1973-7 and numbers admitted after first febrile convulsion under 2 years of age. (Incidences of febrile convulsions per thousand (\%) live births given in parentheses)

\begin{tabular}{|c|c|c|c|c|c|c|c|c|c|c|}
\hline \multirow{2}{*}{$\begin{array}{l}\text { 28-Day } \\
\text { period }\end{array}$} & \multicolumn{2}{|c|}{1973} & \multicolumn{2}{|c|}{1974} & \multicolumn{2}{|c|}{1975} & \multicolumn{2}{|c|}{1976} & \multicolumn{2}{|c|}{1977} \\
\hline & $\begin{array}{l}\text { No of } \\
\text { children }\end{array}$ & $\begin{array}{l}\text { No }(\%) \text { with } \\
\text { convulsions }\end{array}$ & $\begin{array}{l}\text { No of } \\
\text { children }\end{array}$ & $\begin{array}{l}\text { No (\%) with } \\
\text { convulsions }\end{array}$ & $\begin{array}{l}\text { No of } \\
\text { children }\end{array}$ & $\begin{array}{l}\text { No (\%o with } \\
\text { convulsions }\end{array}$ & $\begin{array}{l}\text { No of } \\
\text { children }\end{array}$ & $\begin{array}{l}\text { No }(\%) \text { with } \\
\text { convulsions }\end{array}$ & $\begin{array}{c}\text { No of } \\
\text { children }\end{array}$ & $\begin{array}{l}\text { No }(\% \text { o with } \\
\text { convulsions }\end{array}$ \\
\hline $\begin{array}{r}1 \\
2 \\
3 \\
4 \\
5 \\
6 \\
7 \\
8 \\
9 \\
10 \\
11 \\
12 \\
13\end{array}$ & $\begin{array}{l}482 \\
493 \\
525 \\
474 \\
490 \\
462 \\
499 \\
436 \\
368 \\
450 \\
430 \\
392 \\
443\end{array}$ & $\begin{array}{c}2(4 \cdot 1) \\
7(14 \cdot 2) \\
14(26 \cdot 7) \\
3(6 \cdot 3) \\
9(18 \cdot 4) \\
4(8 \cdot 7) \\
14(28 \cdot 1) \\
5(11 \cdot 5) \\
5(12 \cdot 6) \\
5(11 \cdot 1) \\
3(7 \cdot 0) \\
4(10 \cdot 2) \\
5(11 \cdot 3)\end{array}$ & $\begin{array}{l}436 \\
431 \\
450 \\
421 \\
402 \\
436 \\
413 \\
407 \\
416 \\
441 \\
370 \\
385 \\
360\end{array}$ & $\begin{array}{c}12(27 \cdot 5) \\
11(25 \cdot 5) \\
12(26 \cdot 7) \\
4(9 \cdot 5) \\
11(27 \cdot 4) \\
7(16 \cdot 1) \\
4(9 \cdot 7) \\
1(2 \cdot 5) \\
3(7 \cdot 2) \\
5(11 \cdot 3) \\
7(18 \cdot 9) \\
2(5 \cdot 2) \\
4(11 \cdot 1)\end{array}$ & $\begin{array}{l}444 \\
445 \\
468 \\
437 \\
446 \\
461 \\
444 \\
410 \\
436 \\
446 \\
388 \\
382 \\
377\end{array}$ & $\begin{array}{l}7(15 \cdot 8) \\
6(13 \cdot 5) \\
3(6 \cdot 4) \\
6(13 \cdot 7) \\
6(13 \cdot 5) \\
8(17 \cdot 4) \\
8(18 \cdot 0) \\
9(22 \cdot 0) \\
3(6 \cdot 9) \\
8(17 \cdot 9) \\
8(20 \cdot 6) \\
2(5 \cdot 2) \\
5(13 \cdot 3)\end{array}$ & $\begin{array}{l}398 \\
436 \\
487 \\
420 \\
443 \\
413 \\
463 \\
397 \\
398 \\
426 \\
416 \\
359 \\
390\end{array}$ & $\begin{array}{r}7(17 \cdot 6) \\
12(27 \cdot 5) \\
9(18 \cdot 5) \\
6(14 \cdot 3) \\
8(18 \cdot 1) \\
5(12 \cdot 1) \\
14(30 \cdot 2) \\
12(30 \cdot 2) \\
11(27 \cdot 6) \\
5(11 \cdot 7) \\
7(16 \cdot 8) \\
7(19 \cdot 5) \\
6(15 \cdot 4)\end{array}$ & $\begin{array}{l}391 \\
418 \\
417 \\
409 \\
428 \\
430 \\
426 \\
405 \\
428 \\
459 \\
406 \\
416 \\
405\end{array}$ & $\begin{array}{c}3(7 \cdot 7) \\
8(19 \cdot 1) \\
10(24 \cdot 0) \\
10(24 \cdot 4) \\
8(18 \cdot 7) \\
9(21 \cdot 0) \\
9(21 \cdot 1) \\
5(12 \cdot 3) \\
7(16 \cdot 4) \\
2(4 \cdot 4) \\
2(4 \cdot 9) \\
3(7 \cdot 2) \\
4(9 \cdot 9)\end{array}$ \\
\hline Total & 5944 & $80(13.5)$ & 5368 & $83(15 \cdot 5)$ & 5584 & $79(14 \cdot 1)$ & 5446 & $109(20 \cdot 0)$ & 5438 & $80(14 \cdot 7)$ \\
\hline
\end{tabular}

TABLE II-Incidences of admission for febrile convulsion among liveborn children delivered in each 28-day birth period during 1973-7. Incidences expressed per thousand $(\%)$ live births

$\begin{array}{llllllllllllll}\text { 28-Day period } & 1 & 2 & 3 & 4 & 5 & 6 & 7 & 8 & 9 & 10 & 11 & 12 & 13\end{array}$

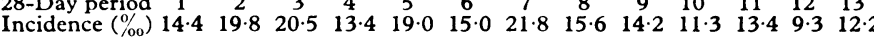

TABLE III-Mean incidences of admission for febrile convulsion among liveborn children delivered in each year of study. Incidences expressed per thousand $(\%)$ live births

\begin{tabular}{|c|c|c|c|c|c|}
\hline $\begin{array}{l}\text { Year of birth } \\
\text { Incidence }(\%)\end{array}$ & $\begin{array}{l}1973 \\
13.5\end{array}$ & $\begin{array}{l}1974 \\
15 \cdot 5\end{array}$ & $\begin{array}{l}1975 \\
14 \cdot 1\end{array}$ & $\begin{array}{l}1976 \\
20 \cdot 0\end{array}$ & $\begin{array}{l}1977 \\
14 \cdot 7\end{array}$ \\
\hline
\end{tabular}

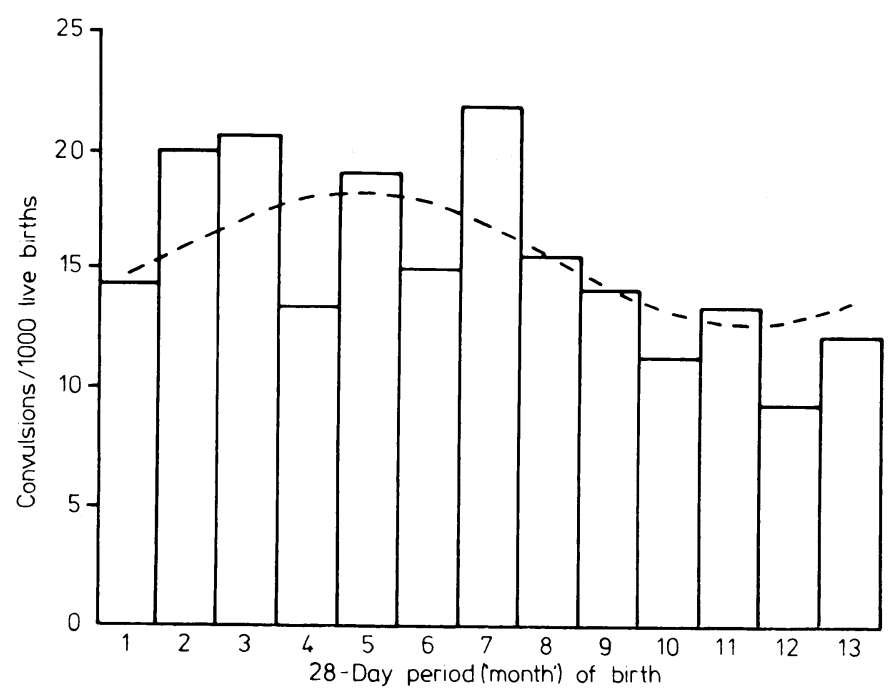

Incidence of febrile convulsions by season of birth (Sheffield 1973-7).

we tested seasonality alone some other pattern might have been missed. In the event the analysis showed significant month-tomonth and year-to-year variation, and further analysis of the data summarised in table II showed that the month-to-month variation was seasonal with expected rates differing by as much as $36 \%$ (fig). We did not go on to look for biannual variations as was done by Cave and Freedman ${ }^{26}$ because the period of oscillation in the data appeared to be about one year and the data were adequately represented by the fitted model.

The statistically significant variation of febrile convulsion rates (range $2 \cdot 5-30 \cdot 2 / 1000$ ) observed in our study suggests that studies based on children born in a few selected months in a particular year would provide an inappropriate sampling frame for this condition. The reasons for the variation in incidence rates of febrile convulsions with month and year of birth are unknown. The heterogeneity of rates for a given "month" across birth cohorts (table $I$ ) is also unexplained. Because this study was based on season of birth rather than date of incident, we could not attempt correlation with the multitude of factors such as the trend of winter virus infections or weather patterns which could alter the appearance of febrile seizure. The observed variation may have been due to a seasonal variation in the cause of febrile convulsions and the age at which children are vulnerable or due to some variation in the response of children to febrile stimuli dependent on seasonal variation in prenatal experience. Our study suggests that the variations observed were not simply due to a random variation in the susceptibility to febrile convulsions. As illegitimate babies have a higher general incidence of disease, the greater fluctuation of illegitimate births superimposed on the seasonal variation in the crude birth rate $^{27}$ might be a partial explanation for the variation in incidence. The distribution of births by parity and maternal age also shows some seasonal variation, ${ }^{12}{ }^{13}$ which might contribute to the variation in disease incidence if a certain parity order or maternal age predisposed to this condition. Aetiological mechanisms argued for other conditions which show seasonal variation in incidence might also apply. ${ }^{12} 142324$

Whatever the reason, the season of birth appears to affect the subsequent development of many diseases, including conditions not generally thought to be seasonally dependent. Consequently unless the independence of date of birth and subsequent development of disease is tested extrapolations from studies confined to particular birth cohorts should be treated with caution. Studies that have been made of children born in a particular week or month have produced invaluable data but have been time consuming and expensive. It remains to be shown that they are representative samples of the nation's children. Statements such as "Since this study represents one week's births, fifty-two times as many defects could be expected in one year in England, Wales, and Scotland"' must be regarded with considerable caution. The April 1958 and subsequent national cohorts have been used to assess the effectiveness of national services (such as the benefit or otherwise of different methods of education ${ }^{28}{ }^{29}$ ). If these cohorts are not representative samples of the nation's children then changes in policy based on extrapolations from these cohorts could be seriously misleading.

We suggest that in future such studies should be based on samples in which all birth cohorts and preferably several years are adequately represented.

We are grateful to the Sheffield Child Development Study for allowing access to their records, and to Professor J L Emery for critical comments. 


\section{References}

${ }^{1}$ Douglas JWB. Maternity in Great Britain. London: Oxford University Press, 1948.

2 Douglas JWB, Blomfield JM. Children under five. London: George Allen and Unwin, 1958.

${ }^{3}$ Spence J, Walton WS, Miller FJW, Court SDM. A thousand families in Newcastle-upon-Tyne. London: Oxford University Press, 1954.

4 Miller FJW, Court SDM, Walton WS, Knox EG. Growing up in Newcastleupon-Tyne. London: Oxford University Press, 1960.

5 Butler NR, Alberman ED. Perinatal problems. Edinburgh: Livingstone, 1969.

- Davie R, Butler N, Goldstein H. From birth to seven. London: Longman, 1972.

${ }^{7}$ Chamberlain R, Chamberlain G, Howlett B, Claireaux A. British births, 1970. London: Heinemann, 1975.

${ }^{8}$ Chamberlain RN, Simpson RN. The prevalence of illness in childhood. Tunbridge Wells: Pitman Medical, 1979.

- Baker RJ, Nelder JA. The GLIM system. Release 3. Generalised linear interactive modelling manual. Oxford, Numerical Algorithms Group, 1979.

10 Walter SD, Elwood JM. A test for seasonality of events with a variable population at risk. British fournal of Preventive and Social Medicine 1975 ;29:18-21.

11 Slatis HM, deCloux RJ. Seasonal variations in stillbirth frequencies. Hum Biol 1967;39:284-94.

12 Sandahl B. Seasonal birth pattern in Sweden in relation to birth order and maternal age. Acta Obstet Gynecol Scand 1978;57:393-6.

13 Janerich DT, Garfinkel J. Season of birth and birth order in relation to prenatal pathology. Am $\mathcal{F}$ Epidemiol 1970;92:351-6.

14 Record RG. Anencephalus in Scotland. British fournal of Preventive and Social Medicine 1961 ;15:93-105.
15 Theander G. Seasonal distribution of births of boys with anomalies of the urethra. Scand f Urol Nephrol 1970;4:1-5.

${ }^{16}$ Harlap S. Time-series analysis of the incidence of Down's syndrome in West Jerusalem. Am 7 Epidemiol $1974 ; 99: 210-7$.

17 Sandahl B. Seasonal incidence of cleft lip and palate in Sweden, 1965-1974. Scand F Plast Reconstr Surg 1978;11:39-43.

18 Sandahl B. Seasonal incidence of some congenital malformations of the central nervous system. Acta Paediatr Scand 1977;66:65-72.

19 Rutstein DD, Nickerson RJ, Heald FP. Seasonal incidence of patent ductus arteriosus and maternal rubella. Am $\mathcal{F} D$ is Child $1952 ; 84: 199-213$.

${ }^{20}$ Janerich DT, Jacobson HI. Seasonality in Down's syndrome. An endocrinological explanation. Lancet $1977 ; \mathrm{i}: 515-6$.

21 Elwood JM. Seasonal variation in anencephalus in Canada. British fournal of Preventive and Social Medicine 1975;29:22-6.

${ }^{22}$ McKeown T, Record RG. Seasonal incidence of congenital malformations of the central nervous system. Lancet $1951 ; \mathrm{i}: 192-6$.

23 Weatherall R. Recent seasonal patterns of infant mortality in England and Wales. In: OPCS. Studies on medical and population subjects. No 31 London: HMSO, 1976.

24 Anonymous. Seasonality of birth in schizophrenia. Lancet 1978;i:481-2.

25 Lloyd B, Pursall E, Emery JL. Hospital morbidity pattern in children under 1 year of age born in Sheffield, 1975-6. Arch Dis Child 1981 ;56: 36-9.

${ }^{26}$ Cave DR, Freedman LS. Seasonal variations in the clinical presentation of Crohn's disease and ulcerative colitis. Int F Epidemiol 1975;4:317-20.

27 Registrar General. Statistical review for 1967. Part III. London: HMSO 1969.

${ }^{28}$ Steedman J. Progress in secondary schools. Findings from the National Child Development Study. London: National Children's Bureau, 1980. 29 Wilby P. Were the school figures fiddled? Sunday Times 1980 Sept 21.

(Accepted 18 November 1981)

\title{
Raised respiratory rate in elderly patients: a valuable physical sign
}

\author{
J P MCFADDEN, R C PRICE, H D EASTWOOD, R S BRIGGS
}

\begin{abstract}
Measurements of respiratory rate in 82 long-stay patients aged 67-101 years yielded a normal range of 16-25 breaths a minute. In a prospective study of 60 consecutive acute admissions to a geriatric unit, 19 out of 21 patients diagnosed as lower respiratory tract infections had respiratory rates above the upper limit of normal on the day of diagnosis; the rise in respiratory rate preceded the clinical diagnosis. All eight patients who were diagnosed on admission as having a lower respiratory tract infection had a respiratory rate greater than 26, with a mean of 29.7 breaths a minute. Patients admitted for other conditions-for example, urinary tract infection -rarely had respiratory rates outside the normal range.

Accurate measurement of respiratory rate is a valuable diagnostic aid in elderly patients.
\end{abstract}

\section{Introduction}

Regular recording of respiratory rate is commonplace in hospital wards, yet it is doubtful that clinicians pay much attention to such observations, particularly as compared with those of

Department of Geriatric Medicine, Centre Block, Level E, Southampton General Hospital, Southampton SO9 4XY

J P MCFADDEN, medical student

R C PRICE, medical student

H D EASTWOOD, MB, FRCP, consultant

R S BRIGGS, MSC, MRCP, senior lecture temperature and pulse rate. Hence a survey of routine measurement of respiratory rate by nurses concluded that it was an expensive tribute to tradition, performed in a perfunctory manner, apt to be highly inaccurate, and of little clinical value. ${ }^{1}$ Lower respiratory tract infections are frequent ${ }^{2}$ (and often terminal $^{3}$ ) events in elderly patients, however, but their onset may be insidious and unaccompanied by a rise in temperature."

Respiratory rate has been suggested as a sensitive index of acute illness in the elderly, ${ }^{5}$ though this has not been evaluated objectively. We have studied prospectively the respiratory rate in two groups of elderly patients: firstly, patients in long-stay wards to assess the variability of the measurement and to define a normal range; and, secondly, patients admitted to acute geriatric wards to observe the effects of acute respiratory or other illness. Inpatients were studied, since we were interested in the effects of illness on a clinical sign in the sick elderly rather than the effects of "normal aging" on the respiratory function of a healthy population.

\section{Patients and methods}

We studied 142 patients. The first group comprised all 82 patients (mean age 83.5 years) in five long-stay wards; 67 were women (mean age 85.4 years, range $73-101$ ) and 15 men (mean age 76.8 years, range 67-88). Respiratory rate in each patient was recorded on several occasions over two to three weeks, at a mean interval of three days (range one to five days); the study of the group as a whole lasted for five weeks. The second group comprised 60 patients (mean age 83.0 years) admitted consecutively to two acute wards; 33 were women (mean age 84.4 years, range $69-94$ ) and 27 men (mean age 81.9 years, range 74-93). These patients were monitored daily, the total period studied being 25 days. 